\title{
The histone deacetylase inhibitor trichostatin A induces cell cycle arrest and rapid upregulation of gadd $45 \beta$ in LS174T human colon cancer cells
}

\author{
Tomoyuki Taniguchi*, Jun Iwashita*\#, Jun Murata, Kenji Ueda, Tatsuya Abe \\ Faculty of Bioresource Sciences, Akita Prefectural University, Akita, Japan \\ Email: \#jun_iwashita@akita-pu.ac.jp
}

Received 9 December 2011; revised 13 January 2012; accepted 20 January 2012

\begin{abstract}
Histone deacetylase (HDAC) inhibitors are considered as promising therapeutic agents against several malignant diseases because they inhibit cancer cell proliferation. The stress sensor genes of the growth arrest and DNA damage-inducible protein (gadd45) family exhibit disordered expression in several types of malignant diseases and are thus a novel target for cancer therapy. However, there have been only few investigations of whether HDAC inhibitors affect the expression of gadd45 genes. We examined the effects of a HDAC inhibitor, trichostatin A (TSA), on the time-dependent expression of gadd45 genes in the human colon cancer cell line LS174T. Addition of TSA to LS174T cells induced inhibition of cell proliferation by arresting the cell cycle. We found that TSA treatment of LS174T cells induced rapid upregulation of gadd45 $\beta$ mRNA expression within $15 \mathrm{~min}$, reaching a peak level at $3 \mathrm{~h}$. Although the time-dependent expression pattern of gadd45 $\beta$ mRNA was similar to that of gadd45 $\beta$ mRNA, the peak level of gadd45 $\beta$ was lower than that of gadd45 $\beta$. TSA treatment also upregulated the mRNA level of $p 21^{\text {Waf1/Cip1 }}$, a proliferation inhibitor, after $3 \mathrm{~h}$, but downregulated the mRNA levels of cyclin D1, a proliferation inducer, after $3 \mathrm{~h}$, and of c-Myc after $1 \mathrm{~h}$. TSA treatment induced a certain level of apoptosis, but the mRNA level of p53, a potent apoptosis inducer, was down-regulated after $3 \mathrm{~h}$. These results suggest that the upregulation of $\mathrm{p}^{2} 1^{\text {Waf1/Cip1 }}$ and apoptosis was independent of p53 and that the early upregulation of gadd45 $\beta$ gene, which precedes the upregulation of $\mathbf{p} 21^{\text {Waf1/Cip1 }}$ and the downregulation of cyclin D1, are important in TSA-treated LS174T cells.
\end{abstract}

Keywords: Histone Deacetylase Inhibitor; Gadd45 Genes; Trichostatin A; LS174T Cells

\footnotetext{
"These authors contributed equally to this work

"Corresponding author.
}

\section{INTRODUCTION}

Eukaryotic transcription occurs as a result of complex interactions among a large number of proteins. Two types of chromatin modification, DNA methylation and histone post-translational modification, are essential for the recruitment of the protein complexes that regulate transcription [1]. Histone deacetylases (HDACs) are one of the prominent protein components that participate in transcriptional regulation. Eighteen human HDACs are classified into four main groups: class I (HDAC1-3, HDAC8); class II (HDAC4-7, HDAC9-10); class III (Sirt1-7); and class IV (HDAC11) [2]. HDACs are not merely catalytic enzymes; they associate with several corepressors, including Sin3 [3], SMRT, and N-CoR [4,5], and participate in transcriptional regulation. Inhibition of cellular HDACs often induces altered expression of several genes. The HDAC inhibitors induce cell cycle arrest or apoptosis in several cancer cell types, and are therefore of interest as a therapeutic agent for several malignant diseases $[6,7]$.

The stress sensor genes of the growth arrest and DNA damage-inducible protein (gadd45) family have been implicated in various cellular stress responses that result in cell cycle arrest, DNA repair, cell survival, cell sensecence, or apoptosis [8]. Gadd45 family consists of gadd $45 \alpha$, gadd $45 \beta$ and gadd $45 \gamma$. Gadd 45 proteins function via a complex interplay of physical interactions with other cellular proteins, including proliferating cell nuclear antigen (PCNA), p2 $1^{\text {Wafl/Cip1 }}$, cyclinB1, p38, and the MAPK kinase kinase MEKK4. Dysregulated expression of gadd45 genes has been observed in several types of malignant diseases, including breast cancer, hepatocellular carcinoma, prostate cancer, and pancreatic cancer. Thus, it is suggested that gadd45 genes belong to a novel target class for cancer therapy $[8,9]$. However, the precise roles of gadd45 genes in malignant diseases remain unclear.

We previously reported that butyrate, which is an HDAC inhibitor of short-chain fatty acids, inhibits proliferation of the human colon cancer cell line LS174T by 
arresting the cell cycle; they also stimulate mRNA and protein production of MUC2 mucin [10]. Despite extensive research on the effects of HDAC inhibitors on cancer cells, the precise mechanisms by which HDAC inhibitors alter gene expression remain unclear. In particular, there have been few investigations of the correlation between HDAC inhibitors and gadd 45 genes, especially in colon cancer cells [11]. Recently, gadd $45 \beta$ has been reported to be regulated by distinct stress-specific mechanisms in human RKO colorectal carcinoma cells [12]. The effects of HDAC inhibitors on gadd45 gene expression may vary in distinct cell culture conditions. Therefore, we examined the effects of the HDAC inhibitor trichostatin A (TSA), which is isolated from Streptomyces hygroscopicus [13] and inhibits class I and class II HDACs, on the time-dependent expression of gadd45 genes in the human colon cancer cell line LS174T.

We found that TSA treatment induced proliferative inhibition of LS174T cells by arresting the cell cycle at G0/G1 phase and increased gadd $45 \beta$ and gadd $45 \alpha$ mRNA expression levels. The upregulation of gadd $45 \beta$ gene in LS174T cells was significantly increased at $15 \mathrm{~min}$ and peaked with a 15-fold increase $3 \mathrm{~h}$ after TSA treatment. The cell cycle inhibitor protein gene $\mathrm{p} 21^{\text {Waf1/Cip1 }}$ was also upregulated $3 \mathrm{~h}$ after TSA treatment. In contrast, expression of the p53 tumor suppressor gene was down-regulated $3 \mathrm{~h}$ after TSA treatment. These results suggest that early upregulation of gadd $45 \beta$ gene is an important event preceding the upregulation of $\mathrm{p} 21^{\mathrm{Waf} 1 / \mathrm{Cip} 1}$, down-regulation of $\mathrm{p} 53$, and subsequent inhibition of proliferation in TSA-treated LS174T cells.

\section{MATERIALS AND METHODS}

\subsection{Cell Culture}

The human colon adenocarcinoma line, LS174T, was purchased from the American Type Culture Collection (MD, USA). The LS174T cells were cultured in Minimum Essential Medium Eagle (MEM, Sigma Aldrich, Japan) supplemented with 10\% fetal bovine serum (FBS, Cansera International, Canada), 1\% non-essential amino acids (Invitrogen, USA), $100 \mathrm{U} / \mathrm{ml}$ penicillin (Gibco Oriental, Japan) and $100 \mu \mathrm{g} / \mathrm{ml}$ streptomycin (Gibco Oriental, Japan) in a $5 \% \mathrm{CO}_{2}$ incubator. The adherent cells were subcultured every 3 - 4 days by treatment with a trypsinEDTA solution (Gibco Oriental, Japan).

\subsection{Cell Proliferation Assay}

LS174T cells were suspended in the culture medium using a syringe with an attached $26 \mathrm{G}$ needle to make a single-cell suspension before counting number. The cells $\left(1 \times 10^{4}\right.$ in $\left.0.1 \mathrm{ml}\right)$ were precultured in a 96 -well plate (Sumilon, Japan) overnight to allow them to adhere. Sub- sequently, various concentration of TSA $(0-2.5 \mu \mathrm{M}$, Cayman Chemical, MI, USA) dissolved in dimethyl sulfoxide (DMSO, final $0.01 \%$ ) was added to the wells in triplicate. The cells were cultured for additional $24 \mathrm{~h}$. After the medium was removed, cells were incubated for $3 \mathrm{~h}$ with $0.1 \mathrm{ml}$ of new medium containing $10 \mu \mathrm{l}$ of the reagent of Cell Counting Kit-8 (Dojin, Japan). Absorbance at $450 \mathrm{~nm}$ was measured by a Microplate reader Model 550 (Bio-Rad, Japan).

\subsection{Detection of Acetylated Histone}

LS174T cells $\left(1 \times 10^{5}\right.$ cells $\left./ \mathrm{ml}\right)$ were precultured overnight and treated with $1 \mu \mathrm{M}$ TSA for additional $24 \mathrm{~h}$. The treated cells were lysed with standard SDS sample buffers. The sample proteins were separated on a $12.5 \%$ SDSpolyacrylamide gel by electrophoresis. Protein bands were then blotted onto a nitrocellulose membrane (Hybond ECL, Amersham Pharmacia Biotech, USA) by standard western blotting methods. Histone $\mathrm{H} 1$ and acetylated histone $\mathrm{H} 3$ were detected with a rabbit anti-histone $\mathrm{H} 1$ antibody (Santa Cruz FL-219, USA) and a rabbit antiacetylated-histone H3 antibody (Upstate \#06-599, USA), respectively and an appropriate anti-rabbit IgG antibody conjugated with horseradish peroxidase (Promega W4011, USA). The enzyme reaction was detected by the previously reported method [10], using an ECL Western Blotting Detection Reagent (Amersham Pharmacia Biotech, UK) and a LAS-1000 Plus image analyzer (Fujifilm, Japan).

\subsection{Flow Cytometry for Cell-Cycle Analysis}

Cell-cycles were analyzed by the previously reported method [10]. Briefly, LS174T cells $\left(5 \times 10^{5}\right.$ cells $\left./ \mathrm{ml}\right)$ were precultured in complete medium $(10 \% \mathrm{FBS})$ overnight, and then starved in incomplete medium $(0.5 \%$ FBS) for 2 days. The cells were again cultured in complete medium supplemented with $1 \mu \mathrm{M}$ TSA for additional $24 \mathrm{~h}$. Cell nuclei were collected from the cells by treatment with $0.1 \%$ Triton X-100 and RNase A, and stained with propidium iodide. The stained nuclei were analyzed using a FACSCalibur flow cytometer with CellQuest software (Becton Dickinson, USA). For each sample, data were obtained through two gates, FSC vs SSC and FL2W vs. FL2A, to exclude emission of doublet nuclei. At least 10,000 nuclei were counted for each sample.

\subsection{Detection of Apoptosis}

LS174T cells $\left(1 \times 10^{5}\right.$ cells $\left./ \mathrm{ml}\right)$ were precultured overnight and treated with $1 \mu \mathrm{M}$ TSA for additional $16 \mathrm{~h}$. The apoptotic rate of treated cells was analyzed by a flow cytometer with a TACS Annexin V Biotin Apoptosis 
Detection Kit (Trevigen, USA) according to the manufacturer's instructions. In another experiment, LS174T cells treated with $1 \mu \mathrm{M}$ TSA for $24 \mathrm{~h}$ were fixed with $10 \%$ formalin, and stained with Hoechst 33,342 fluorescent dye (10 $\mu \mathrm{g} / \mathrm{ml}$, Invitrogen, USA). The stained cells were observed under a fluorescence microscope, BX51 (Olympus, Japan), with excitation at $365 \mathrm{~nm}$ and emission at $400 \mathrm{~nm}$.

\subsection{RT-PCR}

Quantitative RT-PCR was performed by the previously reported method [10,14]. Briefly, cellular RNA was extracted from LS174T cells using a TRIzol reagent (Invitrogen, Japan). Total RNA concentrations were determined using a NanoDrop ND-1000 spectrophotometer (NanoDrop, USA). mRNA levels were measured using a real-time PCR LightCycler System V3 (Roche Molecular Biochemicals, Germany) and a QuantiTect SYBR Green RT-PCR kit (Qiagen, Japan). After one cycle of reverse transcription at $50^{\circ} \mathrm{C}$ for $20 \mathrm{~min}$ and initial activation at $95^{\circ} \mathrm{C}$ for $15 \mathrm{~min}, 45$ cycles of PCR were performed with each cycle of $94^{\circ} \mathrm{C}$ for $15 \mathrm{sec}, 61^{\circ} \mathrm{C}$ for $30 \mathrm{sec}$, and $72^{\circ} \mathrm{C}$ for $45 \mathrm{sec}$. The PCR primers used are shown in Table 1. The identity of the PCR products was confirmed by nucleotide sequencing that was performed in the Biotechnology Center of Akita Prefectural University.

\subsection{Enzyme Activity Assay of HDAC}

The template is used to format your paper and style the text. All margins, column widths, line spaces, and text Nuclear fraction was separated from LS174T cells treated with $1 \mu \mathrm{M}$ TSA for $24 \mathrm{~h}$ using a Nuclear Extraction Kit (Chemicon International, USA). After protein concentration was adjusted, enzyme activity of HDAC was measured with a HDAC Colorimetric Assay/Drug Discovery Kit (Biomol International, USA) according to the manufacturer's instructions. Absorbance at $405 \mathrm{~nm}$ was measured by a microplate reader Model 550.

\subsection{Statistics}

Statistical significance was estimated by an unpaired Student's t-test. The mean fold increases (average \pm SD)

Table 1. The list and all sequences of primers used for PCR analysis.

\begin{tabular}{|c|c|c|}
\hline Primer name & Sequence & Length (bases) \\
\hline gadd $45 \alpha$ forward & 5'-TGACTTTGGAGGAATTCTCGGC-3' & 22 \\
\hline gadd $45 \alpha$ reverse & 5'-ATGAATGTGGATTCGTCACCAGCACGCAGT-3' & 30 \\
\hline gadd $45 \beta$ forward & 5'-AACATGACGCTGGAAGAGCT-3' & 20 \\
\hline gadd $45 \beta$ reverse & 5'-AGAAGGACTGGATGAGCGTG-3' & 20 \\
\hline gadd $45 \gamma$ forward & 5'-AACTAGCTGCTGGTTGATCG-3' & 20 \\
\hline gadd $45 \gamma$ reverse & 5'-CGTTCAAGACTTTGGCTGAC-3' & 20 \\
\hline $\mathrm{p} 21^{\text {Waf1/Cip } 1}$ forward & 5'-GGCTTCATGCCAGCTACTTC-3' & 20 \\
\hline $\mathrm{p} 21^{\text {Wafl } / \text { Cip } 1}$ reverse & 5'-CCCTAGGCTGTGCTCACTTC-3' & 20 \\
\hline cyclin D1 forward & 5'-GGATGCTGGAGGTCTGCGA-3' & 19 \\
\hline cyclin D1 reverse & 5'-AGAGGCCACGAACATGCAAG-3' & 20 \\
\hline p53 forward & 5'-CCTTCCCAGAAAACCTACCA-3' & 20 \\
\hline p53 reverse & 5'-TCATAGGGCACCACCACACT-3' & 20 \\
\hline c-myc forward & 5'-AGCGACTCTGAGGAGGAACA-3" & 20 \\
\hline c-myc reverse & 5'-TCGCCTCTTGACATTCTCCT-3' & 20 \\
\hline HDAC1 forward & 5'-CCAAATGCAGGCGATTCCT-3' & 19 \\
\hline HDAC1 reverse & 5'-AGAATCGGAGAACTCTTCCTCACA-3' & 24 \\
\hline HDAC2 forward & 5'-AAACTGCATATTAGTCCTTCAA-3' & 22 \\
\hline HDAC2 reverse & 5'-TGAGGTAACATGCGCAAATTTT-3' & 22 \\
\hline HDAC3 forward & 5'-GGAGCTGGACACCCTATGAA-3' & 20 \\
\hline HDAC3 reverse & 5'-TATTGGTGGGGCTGACTCTC-3' & 20 \\
\hline
\end{tabular}


against the each control are shown. Asterisks show the statistical probability, ${ }^{\dagger} p<0.05$ and ${ }^{* *} p<0.001$.

\section{RESULTS}

\subsection{TSA Induces Proliferative Inhibition of LS174T Cells by Cell Cycle Arrest}

The HDAC inhibitor TSA induces cell cycle arrest or apoptosis in several cancer cells. We examined the effects of TSA on the proliferation of LS174T cells. The cells were treated with various concentrations of TSA for $24 \mathrm{~h}$. Cell proliferation was inhibited by TSA in a dosedependent manner, and almost ceased with $1 \mu \mathrm{M}$ TSA (Figure 1). The cells treated with $1 \mu \mathrm{M}$ TSA for $24 \mathrm{~h}$ showed accumulation of the acetylated histone $\mathrm{H} 3$, suggesting that TSA inhibited HDAC enzyme activity in the treated cells (Figure 2). Next, we measured the total HDAC enzyme activity in the nuclear fraction separated from the TSA-treated LS174T cells. The enzyme activity was reduced to $40.8 \%$ in the treated cells (Figure 3(a)). We then examined mRNA levels of the typical class I HDACs in the treated cells, namely HDAC1, HDAC2, and HDAC3. The HDAC2 mRNA level was signifycantly reduced, but no large difference in HDAC1 or HDAC3 mRNA levels was detected (Figure 3(b)). The downregulation of HDAC2 seemed to be preferentially induced in the TSA-treated LS174T cells.

Flow cytometry showed that the proportion of $\mathrm{G} 0 / \mathrm{G} 1$ phase cells was increased in the TSA-treated cells (Figure 4(a)). Early apoptosis detected by the binding of annexin V was also induced in the LS174T cells treated with $1 \mu \mathrm{M}$ TSA for $16 \mathrm{~h}$ (Figure 4(b)). Hoechst staining of the nuclei confirmed the phenomenon where only some cells were apoptotic and a substantial number of

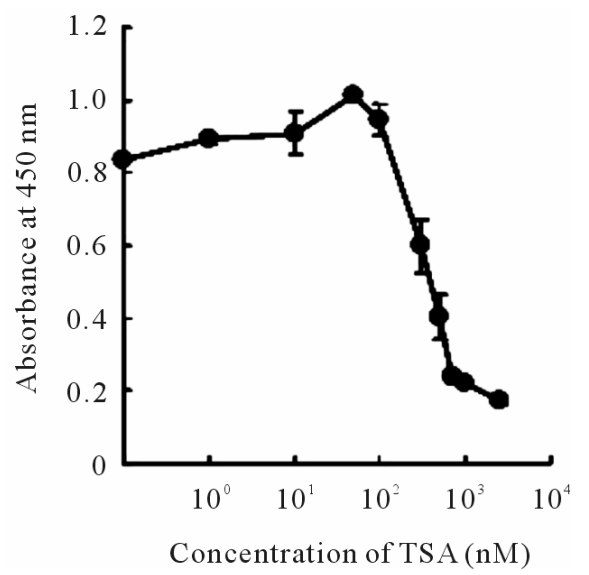

Figure 1. Inhibition of LS174T cell proliferation with TSA treatment. Cells were treated in triplicate with various concentration of TSA for $24 \mathrm{~h}$. Cell proliferation was measured by the Cell Counting Kit- 8 with absorbance at $450 \mathrm{~nm}$.

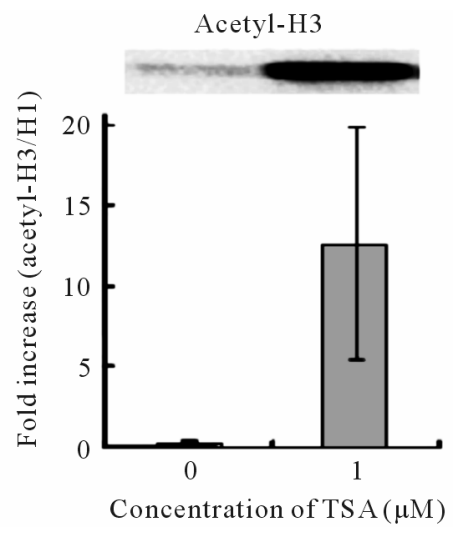

Figure 2. Accumulation of acetylatedhistone $\mathrm{H} 3$ in TSA treated LS174T cells. Cells were treated in triplicate with or without $1 \mu \mathrm{M}$ TSA for $24 \mathrm{~h}$. Cell proteins were separated and analyzed by standard western blotting methods. Histone $\mathrm{H} 1$ and acetylated histone $\mathrm{H} 3$ were detected with an anti-histone $\mathrm{H} 1$ antibody and an antiacetylated-histone H3 antibody, respectively. The mean fold increases of acetylated-histone $\mathrm{H} 3$ /histone $\mathrm{H} 1$ are shown.
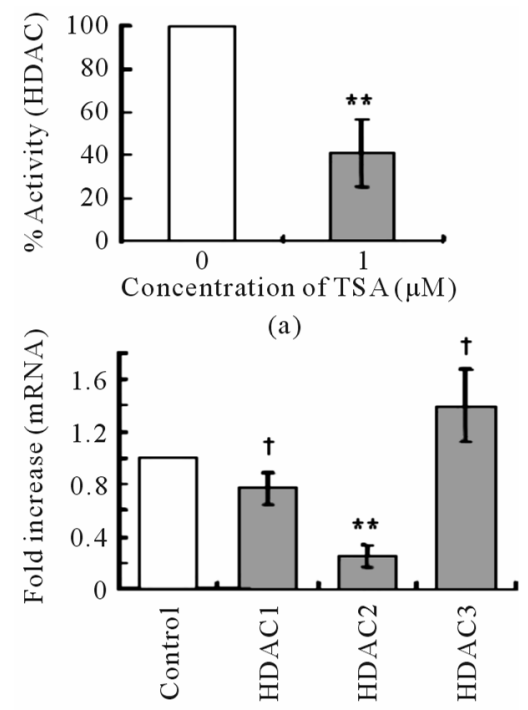

(b)

Figure 3. TSA effects on enzyme activity and mRNA level of HDACs in LS174T cells. (a) Cells were treated with or without $1 \mu \mathrm{M}$ TSA for $24 \mathrm{~h}$. Nuclear fraction was separated from the cells treated with TSA. Total enzyme activity of HDAC in nuclear fraction was measured with a commercial kit. Five samples were used in each treatment; (b) Cells were treated with or without $1 \mu \mathrm{M}$ TSA for $24 \mathrm{~h}$. mRNA levels of HDAC1, HDAC2 and HDAC3 were determined by RT-PCR. Eight samples were used in each TSA treated and no treated control. 


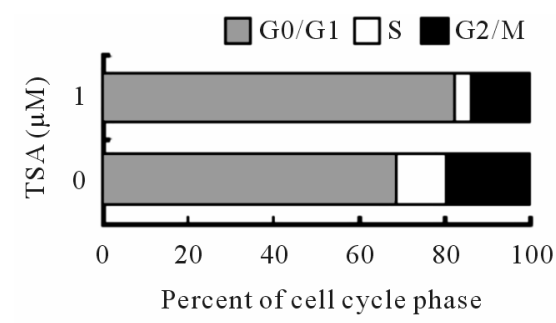

(a)

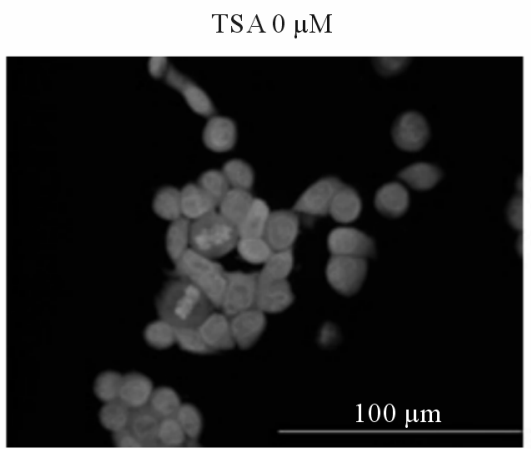

(c)

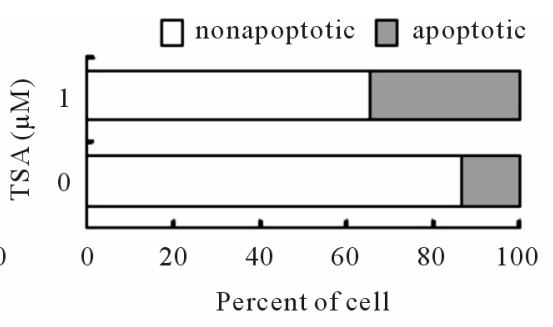

(b)

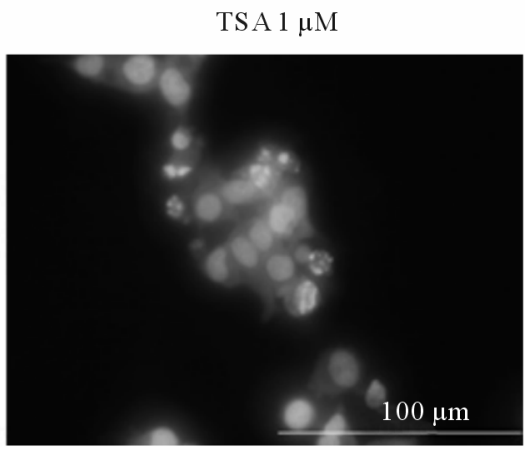

(d)

Figure 4. TSA effects on cell cycle and apoptosis in LS174T cells. (a) Cells were starved in incomplete medium, and then cultured in complete medium with $1 \mu \mathrm{M}$ TSA for $24 \mathrm{~h}$. Cell nuclei were collected, and stained with propidium iodide. The stained nuclei were analyzed by flow cytometry. Ratios of G0/G1 (grey), S (white) and G2/M (black) phases are shown; (b) Cells were treated with $1 \mu \mathrm{M}$ TSA for $16 \mathrm{~h}$. Apoptotic cells were analyzed by flow cytometry using an annexin V binding kit. Ratios of early apoptotic (grey) and viable (white) cells are shown; (c) Cells treated with $1 \mu \mathrm{M}$ TSA for $24 \mathrm{~h}$ were fixed, and stained with Hoechst 33,342 . Photographs were taken by fluorescence microscopy with $\times 400$ magnification.

cells were nonapoptotic. Fragmentation of the nucleus was observed in treated cells, but many cells remained unfragmented after $24 \mathrm{~h}$ of TSA treatment (Figures 4(c), (d)). Therefore, a certain level of apoptosis was induced by TSA treatment, but the inhibition of the proliferation of LS174T cells induced by $1 \mu \mathrm{M}$ TSA for $24 \mathrm{~h}$ was mainly due to cell cycle arrest at the G0/G1 phase.

\subsection{TSA Induces Gadd $45 \beta$ and Gadd $45 \alpha$ mRNA Expressions in LS174T Cells}

Whether HDAC inhibitors affect the expression of gadd45 genes or not is an interesting question. We examined the time-dependent changes in gadd45 mRNA levels in LS174T cells treated with $1 \mu \mathrm{M}$ TSA. Gadd45 $\alpha$ mRNA was upregulated two- or three-fold after $3 \mathrm{~h}$ of TSA treatment (Figure 5(a)). A marked change in gadd $45 \beta \mathrm{mRNA}$ expression was also observed. Upregulation of gadd $45 \beta$ mRNA expression was detected at $15 \mathrm{~min}$, reaching an approximate 15 -fold increase $3 \mathrm{~h}$ after TSA treatment (Figure 5(b)). The gadd $45 \gamma$ mRNA level was not changed during treatment, except for a slight increase at $24 \mathrm{~h} \mathrm{(Fi-}$ gure 5(c)). These results suggest that one of the characteristic effects of TSA may be early upregulation of gadd $45 \beta$ gene in LS174T cells.

\subsection{TSA Modulates the Expression of Cell Cycle-Related Genes in LS174T Cells}

The most common effect of TSA on cancer cells is the upregulation of $\mathrm{p} 21^{\mathrm{Waf} 1 / \mathrm{Cip} 1} \cdot \mathrm{p} 21^{\mathrm{Waf} 1 / \mathrm{Cip} 1}$ expression is usually regulated by $\mathrm{p} 53$, which binds to the $\mathrm{p} 21^{\text {Waf1/Cip } 1}$ promoter. We examined the time-dependent effect of TSA on the expression of cell cycle-related genes in LS174T cells. Induction of $\mathrm{p} 21^{\text {Waf1/Cip } 1} \mathrm{mRNA}$ was observed after $3-24 \mathrm{~h}$ in the TSA-treated cells. The $\mathrm{p} 21^{\text {Wafl/Cip1 }} \mathrm{mRNA}$ level was increased more than threefold after $6 \mathrm{~h}$ (Figure 6(a)). However, the p53 mRNA level was decreased after $3 \mathrm{~h}$ in the TSA-treated cells (Figure 6(b)), suggesting p53-independent upregulation of $\mathrm{p} 21^{\text {Waf1/Cip1 }}$. The cyclin D1 mRNA level was also decreased after $3 \mathrm{~h}$ (Figure 6(c)). The proto-oncogene cMyc is overexpressed in many cancer cells, including colon carcinomas [15] and is critical for switching the p53dependent response from cell cycle arrest to apoptosis [16]. Therefore, we examined time-dependent changes in c-Myc mRNA expression in TSA-treated LS174T cells. The c-Myc mRNA level was decreased after $1 \mathrm{~h}$ of TSA 


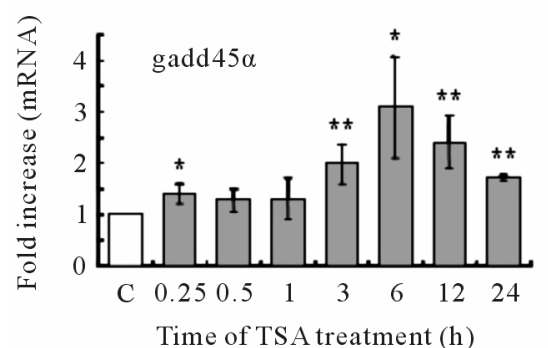

(a)

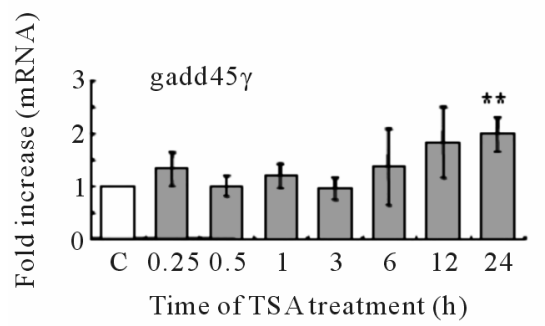

(c)

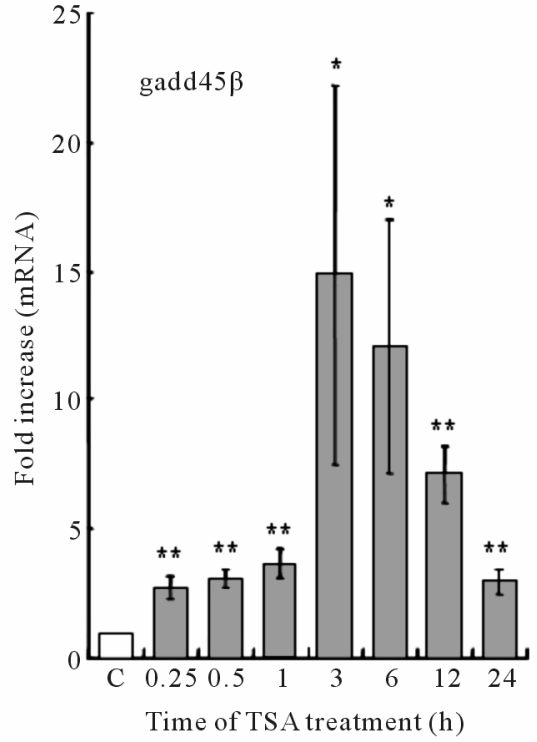

(b)

Figure 5. Time dependent mRNA levels of gadd45 family in TSA treated LS174T cells. Cells were treated with or without $1 \mu \mathrm{M}$ TSA for indicated time. Six samples were used in both TSA treated and no treated control (C) at each time point. mRNA levels of (a) gadd $45 \alpha$; (b) gadd $45 \beta$ and (c) gadd $45 \gamma$ were determined by RT-PCR.

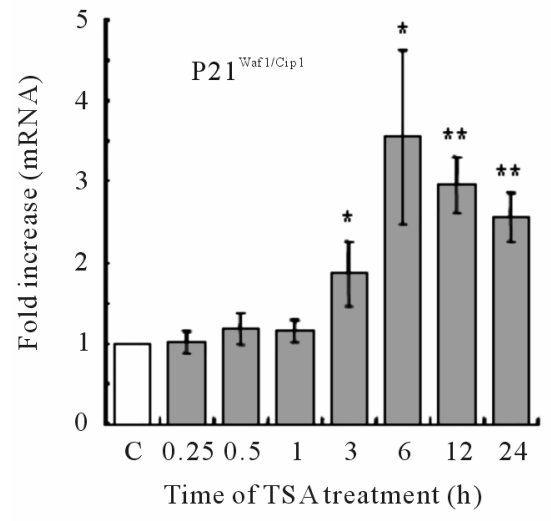

(a)

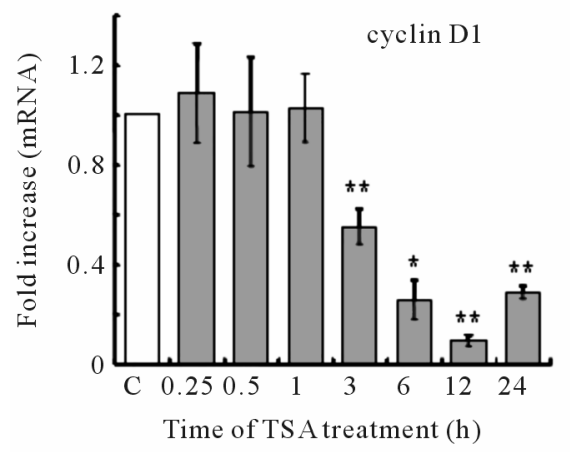

(c)

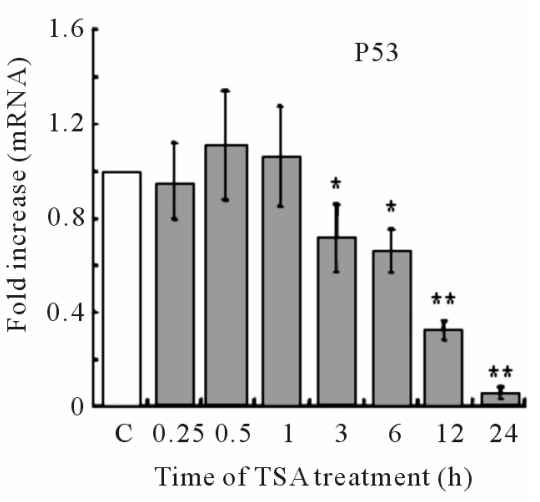

(b)

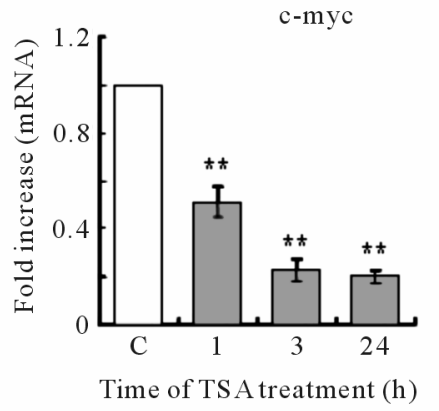

(d)

Figure 6. Time dependent effects of TSA on mRNA levels of some genes in LS174T cells. Cells were treated with or without $1 \mu \mathrm{M}$ TSA for indicated time. Six or five samples were used in both TSA treated and no treated control (C) at each time point. mRNA levels of (a) p21 Waf1/Cip1 ; (b) p53; (c) Cyclin D1 and (d) c-myc were determined by RT-PCR. 
treatment (Figure 6(d)).

\section{DISCUSSION}

The most common effect of TSA on cancer cells is the Two theories have been proposed regarding p53 transcriptional activity in response to stress. One is the prebinding event theory that states that stress inducesp53 binding only to genes that need to be regulated. Another is the post-binding event theory that states that p53 binds most of its response elements and that post-binding events operate as filters to allow transcription of specific genes. Millau et al. have recently shown that the pre- and postbinding events act together to regulate adapted stress responses [17]. It has been reported that TSA causes p53 to switch oxidative-damaged cells from cell cycle arrest to apoptosis and promotes $\mathrm{p} 21^{\text {Waf1/Cip1 }}$ mRNA expression in HCT116 p53 ${ }^{+/+}$colorectal cancer cells [18]. Another report concerning $\mathrm{p} 21^{\text {Waf1/Cip1 }}$ expression has indicated that a novel zinc finger protein, Zac1, which acts as a transcriptional cofactor for $\mathrm{p} 53$, functions synergistically with $\mathrm{p} 53$ or TSA to enhance $\mathrm{p} 21^{\text {Waf1/Cip1 }}$ promoter activity by physically interacting with nuclear receptor corepressors in HeLa cells, suggesting that TSA-induced $\mathrm{p} 21^{\text {Waf1/Cip1 }}$ expression might be mediated through a p53independent pathway [19-22].

HDAC inhibitors can induce cell cycle arrest or apoptosis in many cancer cells [6]. Inhibition of proliferation of LS174T cells was effectively induced by $24 \mathrm{~h}$ treatment with $1 \mu \mathrm{M}$ TSA in our experiments. The inhibition was mainly due to cell cycle arrest and not apoptosis. LS174T cells are known to have functional wild-type p53 and mutated BAX genes [23] and may therefore be resistant to apoptosis induced by TSA. In our experiments, upregulation of $\mathrm{p} 21^{\text {Wafl/Cip1 }}$ expression was observed after $3 \mathrm{~h}$ of TSA treatment. However, p53 expression was downregulated after $3 \mathrm{~h}$. These results suggest that the upregulation of $\mathrm{p} 21^{\mathrm{Waf} 1 / \mathrm{Cip} 1}$ is independent of $\mathrm{p} 53$ in LS174T cells (Figure 6). However, there still remains the possibility that both p53-independent and p53-dependent pathway are involved. To show more clearly, that the p21 is increased p53-independently, we must investigate the stability of the p53 protein. The stability of p53 is regulated by the oncoprotein Mdm2, which mediates p53 ubiquitylation and degradation [24]. In future work, we will investigate Mdm2 activity and the turnover rate and stability of p53 in TSA treated cells.

The gadd45 genes Gadd45 protein has been reported to physically interact with p21 protein and inhibits cell proliferation [25]. Our results, that the early upregulation of gadd $45 \beta$ gene precedes the upregulation of $\mathrm{p} 21^{\text {Waf } 1 / \text { Cip } 1 \text {, }}$ suggest that gadd $45 \beta$ induces the upregulation of $\mathrm{p} 21$ protein and cell cycle arrest (Figures 5(b), 6(a)).

We also found that the c-Myc mRNA level was down- regulated after at least $1 \mathrm{~h}$ of TSA treatment. At that time, $\mathrm{p} 21^{\text {Waf1/Cip1 }}$ mRNA expression was not yet upregulated, although gadd $45 \beta$ mRNA expression was upregulated after 15 min of TSA treatment. We speculate that c-Myc downregulation may be involved in the $\mathrm{p} 21^{\mathrm{Waf1} / \mathrm{Cip} 1}$ upregulation induced by HDAC inhibition in LS174T cells. The c-Myc is highly expressed in many types of cancers $[15,26]$. The strong downregulation of c-Myc by TSA treatment suggests that TSA might useful for cancer therapy by c-Myc downregulation (Figure 6(d)).

The gadd45 family of stress sensor genes is implicated in various cellular stress responses that result in cell cycle arrest, cell survival, cell senescence, or apoptosis. Gadd45 proteins physically interact with some cell cycle-related proteins, including $\mathrm{p} 21^{\text {Waf1/Cip } 1}$; however, their detailed functioning, especially that of gadd $45 \beta$ remains unknown $[8,9]$. We found that gadd $45 \beta$ mRNA expression was upregulated after $15 \mathrm{~min}$ of TSA treatment and was increased approximately 15 -fold at $3 \mathrm{~h}$ in LS174T cells. The TSA-induced modulation of gadd $45 \beta$ mRNA expression preceded the upregulation of $\mathrm{p} 21^{\mathrm{Waf} 1 / \mathrm{Cip} 1}$ and the downregulation of $\mathrm{p} 53$. These results suggest that the early upregulation of gadd $45 \beta$ gene is an important event in response to stress and that an interesting relationship exist between TSA and gadd $45 \beta$.

These findings should encourage further studies of the precise mechanisms by which HDAC inhibitors alter gadd45 genes and the precise roles of gadd45 genes in malignant diseases.

\section{ACKNOWLEDGEMENTS}

This work was supported in part by a grant from the President-Sponsored Research Projects of Akita Prefectural University. We thank the staff of the Biotechnology Center in Akita Prefectural University for their help in DNA sequence analysis. We thank Professor Hiroetsu Wabiko of Akita Prefectural University for helpful discussions.

\section{REFERENCES}

[1] Berger, S.L. (2007) The complex language of chromatin regulation during transcription. Nature, 447, 407-412. doi:10.1038/nature 05915

[2] Hess-Stumpp, H., Bracker, T.U., Henderson, D. and Politz, O. (2007) MS-275, a potent orally available inhibitor of histone deacetylases-The development of an anti cancer agent. The International Journal of Biochemistry \& Cell Biology, 39, 1388-1405. doi:10.1016/j.biocel.2007.02.009

[3] Silverstein, R.A. and Ekwall, K. (2005) Sin3: A flexible regulator of global gene expression and genome stability. Current Genetics, 47, 1-17. doi: 10.1007/s00294-004-0541-5

[4] Li, J., Wang, J., Nawaz, Z., Liu, J.M., Qin, J. and Wong, J. (2000) Both corepressor proteins SMRT and N-CoR exist 
in large protein complexes containing HDAC3. Embo Journal, 19, 4342-4350. doi:10.1093/emboj/19.16.4342

[5] Gao, Z., Chiao, P., Zhang, X., Lazar, M.A., Seto, E., Young, H.A. and Ye, J. (2005) Coactivators and corepressors of NF- $\kappa \mathrm{B}$ in $\mathrm{I} \kappa \mathrm{B} \alpha$ gene promoter. Journal of Biological Chemistry, 280, 21091-21098. doi:10.1074/jbc.M500754200

[6] Riester, D., Hildmann, C. and Schwienhorst, A. (2007) Histone deacetylase inhibitors-Turning epigenic mechanisms of gene regulation into tools of therapeutic intervention in malignant and other diseases. Applied Microbiological Biotechnology, 75, 499-514. doi:10.1007/s00253-007-0912-1

[7] Pulukuri, S.M., Gorantla, B. and Rao, J.S. (2007) Inhibition of histone deacetylase activity promotes invasion of human cancer cells through activation of urokinase plasminogen activator. Journal of Biological Chemistry, 282, 35594-35603. doi: 10.1074/jbc.M705867200

[8] Cretu, A., Sha, X., Tront, J., Hoffman, B. and Liebermann, D.A. (2009) Stress sensor Gadd45 genes as therapeutic targets in cancer. Cancer Therapy, 7, 268-276.

[9] Hoffman, B. and Liebermann, D.A. (2009) Gadd45 modulation of intrinsic and extrinsic stress responses in myeloid cells. Journal of Cell Physiology, 218, 26-31. doi:10.1002/jep.21582

[10] Hatayama, H., Iwashita, J., Kuwajima, A. and Abe, T. (2007) The short chain fatty acid, butyrate, stimulates MUC2 mucin production in the human colon cancer cell line, LS174T. Biochemical and Biophysical Research Communications, 356, 599-603. doi:10.1016/j.bbrc.2007.03.025

[11] Chen, Z., Clark, S., Birkeland, M., Sung, C.M., Lago, A., Liu, R., Kirkpatrick, R., Johanson, K., Winkler, J.D. and $\mathrm{Hu}$, E. (2002) Induction and superinduction of growth arrest and DNA damage gene 45 (GADD45) $\alpha$ and $\beta$ messenger RNAs by histone deacetylase inhibitors trichostatin A (TSA) and butyrate in SW620 human colon carcinoma cells. Cancer Letters, 188, 127-140. doi:10.1016/S0304-3835(02)00322-1

[12] Zumbrun, S.D., Hoffman, B. and Liebermann, D.A. (2009) Distinct mechanisms are utilized to induce stress sensor gadd $45 \beta$ by different stress stimuli. Journal of Cell Biochemistry, 108, 1220-1231. doi:10.1002/jcb.22354

[13] Yoshida, M., Furumai, R., Nishiyama, M., Komatsu, Y., Nishino, N. and Horinouchi, S. (2001) Histone deacetylase as a new target for cancer chemotherapy. Cancer Chemotherapy and Pharmacology, 48, S20-S26. doi:10.1007/s002800100300

[14] Iwashita, J., Yamamoto, T., Sasaki, Y. and Abe, T. (2010) MUC5AC production is downregulated in NCI-H292 lung cancer cells cultured on type-IV collagen. Molecular Cell Biochemistry, 337, 65-75. doi: 10.1007/s11010-009-0286-Z

[15] Erisman, M.D., Rothberg, P.G., Diehl, R.E., Morse, C.C., Spandorfer, J.M. and Astrin, S.M. (1985) Deregulation of c-myc gene expression in human colon carcinoma is not accompanied by amplification or rearrangement of the gene. Molecular and Cellular Biology, 5, 1969-1976. doi:10.1128/MCB.5.8.1969

[16] Seoane, J., Le, H.V. and Massague, J. (2002) Myc suppression of the $\mathrm{p} 21(\mathrm{Cip} 1) \mathrm{Cdk}$ inhibitor influences the outcome of the p53 response to DNA damage. Nature, 419, 729-734. doi:10.1038/nature01119

[17] Millau, J.F., Bastien, N., Bouchard, E.F. and Drouin, R. (2009) p53 pre- and post-binding event theories revisited: Stresses reveal specific and dynamic p53-binding patterns on the p 21 gene promoter. Cancer Research, 69, 84638471. doi: 10.1158/0008-5472.CAN-09-2036

[18] Habold, C., Poehlmann, A., Bajbouj, K., Hartig, R., Korkmaz, K.S., Roessner, A. and Schneider-Stock, R. (2008) Trichostatin A causes p53 to switch oxidative-damaged colorectal cancer cells from cell cycle arrest into apoptosis. Journal of Cellular and Molecular Medicine, 12, 607-621. doi:10.1111/j.1582-4934.2007.00136.x

[19] Liu, P.Y., Chan, J.Y., Lin, H.C., Wang, S.L., Liu, S.T., Ho, C.L., Chang, L.C. and Huang, S.M. (2008) Modulation of the cyclin-dependent kinase inhibitor $\mathrm{p} 21^{\mathrm{WAF} 1 / \mathrm{Cip} 1}$ gene by Zac1 through the antagonistic regulators $\mathrm{p} 53$ and histone deacetylase 1 in HeLa Cells. Molecular Cancer Research, 6, 1204-1214. doi:10.1158/1541-7786.MCR-08-0123

[20] Ocker, M. and Schneider-Stock, R. (2007) Histone deacetylase inhibitors: Signalling towards $\mathrm{p} 21^{\text {cip1/wafl }}$. The International Journal of Biochemistry \& Cell Biology, 39, 1367-1374. doi:10.1016/j.biocel.2007.03.001

[21] Li, H. and Wu, X. (2004) Histone deacetylase inhibitor, Trichostatin A, activates $\mathrm{p} 21^{\mathrm{WAF} 1 / \mathrm{CIP} 1}$ expression through downregulation of c-myc and release of the repression of c-myc from the promoter in human cervical cancer cells. Biochemical and Biophysical Research Communications, 324, 860-867. doi:10.1016/j.bbrc.2004.09.130

[22] Schepeler, T., Mansilla, F., Christensen, L.L., Orntoft, T. F. and Andersen, C.L. (2007) Clusterin expression can be modulated by changes in TCF1-mediated Wnt signaling. Journal of Molecular Signaling, 2, 6. doi:10.1186/1750-2187-2-6

[23] Violette, S., Poulain, L., Dussaulx, E., Pepin, D., Faussat, A. M., Chambaz, J., Lacorte, J.M., Staedel, C. and Lesuffleur, T. (2002) Resistance of colon cancer cells to longterm 5-fluorouracil exposure is correlated to the relative level of Bcl-2 and Bcl-X(L) in addition to Bax and p53 status. International Journal of Cancer, 98, 498-504. doi:10.1002/ijc. 10146

[24] Oliner, J.D., Pietenpol, J.A., Thiagalingam, S., Gyuris, J., Kinzler, K.W. and Vogelstein, B. (1993) Oncoprotein MDM2 conceals the activation domain of tumour suppressor p53. Nature, 362, 857-860. doi:10.1038/362857a0

[25] Kearsey, J.M., Coates, P.J., Prescott, A.R., Warbrick, E. and Hall, P.A. (1995) Gadd45 is a nuclear cell cycle regulated protein which interacts with $\mathrm{p} 21(\mathrm{Cip} 1)$. Oncogene, 11, 1675-1683.

[26] Arvanitis, C. and Felsher, D.W. (2006) Conditional transgenic models define how MYC initiates and maintains tumorigenesis. Seminars in Cancer Biology, 16, 313-317. doi:10.1016/j.semcancer.2006.07.012 